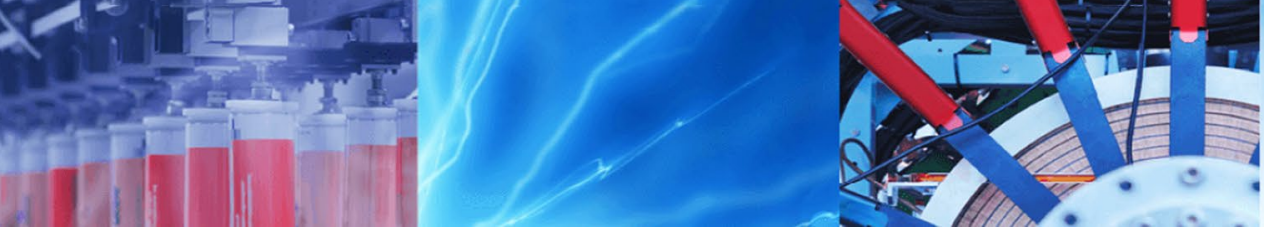

Research Article

\title{
Assessment of natural radioactivity and its radiological hazards in several types of cement used in Senegal
}

\author{
Ousmane Ndour ${ }^{1}$ D $\cdot$ Coumba Thiandoume ${ }^{1} \cdot$ Alassane Traore $^{2} \cdot$ Xavier Cagnat $^{3} \cdot$ Papa Mbaye Diouf $^{1}$.

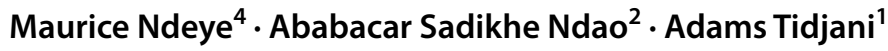

Received: 28 August 2020 / Accepted: 18 November 2020 / Published online: 25 November 2020

(c) Springer Nature Switzerland AG 2020

\begin{abstract}
In this study, the activity concentrations of ${ }^{226} \mathrm{Ra},{ }^{232} \mathrm{Th}$ and ${ }^{40} \mathrm{~K}$ in twenty cement samples of four types (CEM, CEM II, CEM III, and CEM IV) collected from building material suppliers in Senegal were measured using a low-background digital gamma-ray spectrometer equipped with broad energy germanium detector. The activity concentrations of ${ }^{226} \mathrm{Ra},{ }^{232} \mathrm{Th}$ and ${ }^{40} \mathrm{~K}$ varied from 7.1-150.3 $\mathrm{Bq} \mathrm{kg}^{-1}$, 3.7-16.1 $\mathrm{Bq} \mathrm{kg}^{-1}$, and $48.7-133.9 \mathrm{~Bq} \mathrm{~kg}^{-1}$, respectively. Also, possible radiological risks from the usage of these materials were assessed by estimating external and internal index, indoor absorbed gamma dose rate and the corresponding annual effective dose, effective dose rate to different body organs and tissus, and excess lifetime cancer risk. The estimated radiological hazard indices were revised in light of the relevant national and international legislation and guidance. The values of the radiological hazard indices were found to be within relevant all limit values for structural building materials.
\end{abstract}

Keywords Natural radiouclides · Gamma-ray spectrometry · Activity concentrations · radiological hazards indices . Cement

\section{Introduction}

Humans are continuously exposed to natural radiation which comes from cosmogenic radionuclides and primordial radionuclides [1]. The cosmogenic radionuclides are continuously produced in the upper part of the atmosphere by the interaction of the cosmic radiation with atoms or molecules. The primordial radionuclides are the uranium series with as parent the ${ }^{238} \mathrm{U},{ }^{235} \mathrm{U}$ series or actinium series, thorium $\left({ }^{232} \mathrm{Th}\right)$ series, and ${ }^{40} \mathrm{~K}$ which is a non-series of disintegration. When dealing with naturally occurring radioactive material (NORM), only the primordial radionuclides are of radiological interest. Depending on the geological origin of the raw materials (rocks, soil, and industrial products), the building materials may contain different amounts of natural radionuclides $[2,3]$. As cement is most used in building material, it can become a health and environmental problem for the population. According to Mansoor et al., individuals spend $80 \%$ of their time at home or office indoor [4]. It is then important to estimate the natural radioactivity in cement.

There are different exposition ways of humans by radionuclides content in cement: internal and external exposure. Internal exposure is due to the inhalation of radon $\left({ }^{222} \mathrm{Rn}\right)$ which emanates from the building material [5]. During the inhalation, radon may decay in the track respiratory conducting to the deposition of its progenies and becomes a permanent source of internal exposure [6]. External exposure is due to the emission of $\gamma$-rays by

Ousmane Ndour, ousmanendour9031@gmail.com | ${ }^{1}$ Natural and Artificial Radiation Laboratory, Department of Physics, Cheikh Anta Diop University, Dakar, Senegal. ${ }^{2}$ Institute of Applied Nuclear Technology, Cheikh Anta Diop University, Dakar, Senegal. ${ }^{3}$ Nuclear Safety and Radiation Protection Institute, Orsay, France. ${ }^{4}$ Carbon-14 Laboratory, Cheikh Anta Diop University, Dakar, Senegal. 
primordial radionuclides $\left({ }^{226} \mathrm{Ra},{ }^{232} \mathrm{Th}\right.$, and their daughters and $\left.{ }^{40} \mathrm{~K}\right)$.

In Senegal, there are three factories of cement, but so far, no data concerning natural radioactivity of cement used are available. To fill this gap, the main objectives of this study are to assess the ${ }^{226} \mathrm{Ra},{ }^{232} \mathrm{Th}$, and ${ }^{40} \mathrm{~K}$ activity concentrations and the radiological hazards in the types of cement used as a building material.

\section{Materials and methods}

\subsection{Sample collection and preparation}

Twenty cement samples were collected from building material suppliers and labeled properly. The net weight of the collected samples was $1 \mathrm{~kg}$. The gray samples were manufactured by three different domestic cement factories (CEM I, CEM II, and CEM III). To remove moisture, the collected samples were dried at $105^{\circ} \mathrm{C}$ for $24 \mathrm{~h}$ and then transferred to $60 \mathrm{~mL}$ of cylindrical containers with an internal diameter of $72 \mathrm{~mm}$.

\subsection{Gamma-ray spectrometry}

The ${ }^{226} \mathrm{Ra},{ }^{232} \mathrm{Th}$, and ${ }^{40} \mathrm{~K}$ activity concentrations were measured using a calibrated broad energy germanium (BEGe) detectors with a relative efficiency of $50 \%$ at $1332 \mathrm{keV}$ and an energy resolution of $0.7 \mathrm{keV}$ for $60 \mathrm{keV}$ and $1.8 \mathrm{keV}$ for $1332 \mathrm{keV}$ gamma-rays for ${ }^{241} \mathrm{Am}$ and ${ }^{60} \mathrm{Co}$, respectively. The detectors were calibrated to energy and efficiency using a mixed radionuclides standard containing ${ }^{241} \mathrm{Am},{ }^{210} \mathrm{~Pb},{ }^{139} \mathrm{Ce},{ }^{137} \mathrm{Cs},{ }^{113} \mathrm{Sn},{ }^{109} \mathrm{Cd},{ }^{88} \mathrm{Y},{ }^{85} \mathrm{Sr},{ }^{60} \mathrm{Co},{ }^{57} \mathrm{Co}$, and ${ }^{51} \mathrm{Cr}$. The sample analysis was conducted by Genie 2000 software program. The samples were measured at least $80,000 \mathrm{~s}$. As in a planar BEGe detector, the sample is placed on the top of the detector, the coincidences summing were corrected using correction factors calculated by the Monte Carlo simulation, using the GESPECOR software package. For self-attenuation correction, a transmission bench was used for the low energies (below $100 \mathrm{keV}$ ). The principle of transmission bench consists to detect gamma-rays emitted by a collimated source of ${ }^{133} \mathrm{Ba}$ and ${ }^{109} \mathrm{Cd}$ passing through a container, then a sample within its container. A schematic diagram of the transmission bench is shown in Fig. 1.

The attenuation coefficient $\left(\mu_{1}\right)$ was calculated following the Beer-Lambert equation:

$N=N_{0} e^{-\mu \rho x}$

where $N, N_{0}, \rho$, and $x$ represent, respectively, the number of photons having passed through the sample within the

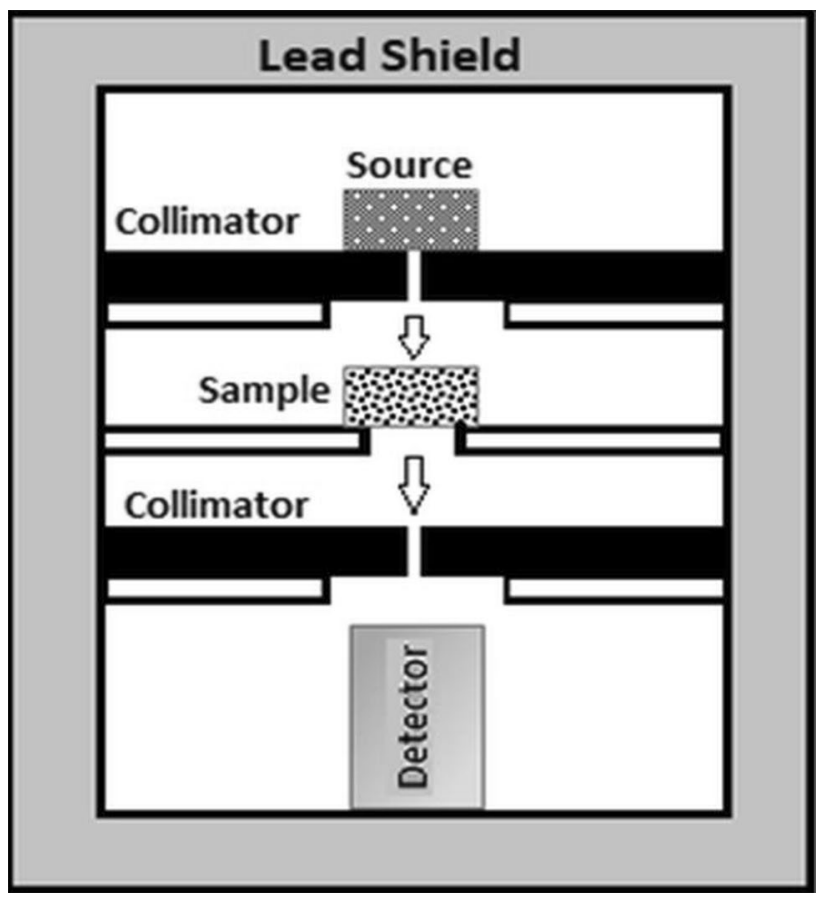

Fig.1 Diagram of transmission bench

geometry, the number of photons detected after crossing the empty geometry, the sample density, and the thickness.

The self-attenuation correction factor $\left(F_{\text {att }}\right)$ was calculated using the following equation:

$F_{\text {att }}=\frac{1-e^{-\mu \rho x}}{\mu \rho x}$

where $x, \mu$, and $\rho$ represent the thickness of the sample, the coefficient of attenuation, and the density, respectively.

As the matrix and the density of the measured samples were different from that of the calibration source, the self-attenuation of the measured samples and the calibration source is therefore different. The relative selfattenuation correction factor $\mathrm{FC}_{\text {self }}(E)$ is determined by the ratio of the self-attenuation correction factor of the sample to that of the calibration source.

$\mathrm{FC}_{\text {self }}(E)=\frac{F_{\text {att.sam }}}{F_{\text {att.ref }}}$

where $F_{\text {att.sam }}$ and $F_{\text {att.ref }}$ are the self-attenuation correction factors of the sample the calibration source, respectively.

The self-attenuation correction factors calculated for ten energies from the transmission source according to their energies were plotted. The interpolated curve obtained was used to calculate the self-attenuation correction factor at other energies. 
The ${ }^{226} \mathrm{Ra}$ activity concentration has been estimated using the $186.2 \mathrm{keV}$ gamma-ray. Since the ${ }^{235} \mathrm{U}$ energy peak at $163 \mathrm{keV}$ has not been identified, the gamma-ray interference between ${ }^{226} \mathrm{Ra}$ at $186.2 \mathrm{keV}$ with a peak of ${ }^{235} \mathrm{U}$ at $185.7 \mathrm{keV}$ was resolved taking into account the ratio of ${ }^{238} \mathrm{U} /{ }^{235} \mathrm{U}=21.7$ and the full energy peak of ${ }^{234} \mathrm{Th}$ at $63.3 \mathrm{keV}$ [7]. The activity concentration of ${ }^{232} \mathrm{Th}$ was estimated using the full energy peaks of ${ }^{228} \mathrm{Ac}$ at $911.2 \mathrm{keV}$ and ${ }^{208} \mathrm{TI}$ at $583.2 \mathrm{keV}$ taking into account the braching ratio. For ${ }^{40} \mathrm{~K}$ activity concentration calculation, its peak at $1460.8 \mathrm{keV}$ was used. The following equation was used to calculate the activity concentration of each radionuclide:

$A\left(\mathrm{Bqkg}^{-1}\right)=\frac{N_{\text {net }}}{P\left(E_{\mathrm{i}}\right) \times \varepsilon\left(E_{\mathrm{i}}\right) \times t \times m \times F_{\mathrm{c}}}$

where $N_{\text {net }}$ represents the net counts under the full absorption peak, $P\left(E_{\mathrm{i}}\right)$ the emission intensity, $\varepsilon\left(E_{\mathrm{i}}\right)$ the detector efficiency at energy $E_{\mathrm{i}}, t$ the counting time, $m$ the sample mass, and $F_{\mathrm{c}}$ the corrective factors taking into account the radioactive decay, the self-attenuation, and the coincidence summing.

\subsection{Dose parameters and radiological hazards indices}

\subsubsection{Absorbed gamma dose rate}

At a height of $1 \mathrm{~m}$ above the ground, the indoor absorbed gamma dose rate $(D)$ due to $\gamma$-ray emitted by ${ }^{226} \mathrm{Ra},{ }^{232} \mathrm{Th}$, and ${ }^{40} \mathrm{~K}$ is evaluated by the following equation $[8,9]$ :

$D\left(\mathrm{nGyh}^{-1}\right)=0.92 A_{\mathrm{Ra}-226}+1.1 A_{\mathrm{Th}-232}+0.08 A_{\mathrm{K}-40}$

The conversion coefficients of ${ }^{226} \mathrm{Ra},{ }^{232} \mathrm{Th}$, and ${ }^{40} \mathrm{~K}$ activity concentrations into dose for materials used as building materials are $0.92,1.1$, and 0.08 in $\mathrm{nGy} \mathrm{h} \mathrm{h}^{-1} / \mathrm{Bq} \mathrm{kg}^{-1}$, respectively. These conversion coefficients were calculated by the Monte Carlo method using a standard room model of $2.8 \mathrm{~m} \times 4 \mathrm{~m} \times 5 \mathrm{~m}$ in which the wall width is $20 \mathrm{~cm}$ and the density $2.35 \mathrm{~g} \cdot \mathrm{cm}^{-3}[10]$.

\subsubsection{Annual effective dose equivalent}

The annual effective dose equivalent (AEDE) was calculated by the following equation [10]:

\subsubsection{Annual gonadal dose equivalent}

Since the gonads are organs of interest, the annual gonadal dose equivalent (AGDE) was calculated using the following equation [11-14]:

$\operatorname{AGDE}\left(\mu \mathrm{SV} . \mathrm{y}^{-1}\right)=3.09 A_{\mathrm{Ra}-226}+4.18 A_{\mathrm{Th}-232}+0.314 A_{\mathrm{K}-40}$

\subsubsection{Gamma index and alpha index}

The gamma index $\left(I_{\gamma}\right)$ was calculated to find out if the cements had met the safety requirements for building materials by the following equation $[2,8]$ :

$I_{\gamma}=\frac{A_{\mathrm{Ra}-226}}{300}+\frac{A_{\mathrm{Th}-232}}{200}+\frac{A_{\mathrm{K}-40}}{3000}$

For material used in a bulky amount, the exemption criterion and the upper dose limit are defined. The exemption criterion $\left(0.3 \mathrm{mSv}^{-1}\right)$ corresponds to $I_{\gamma} \leq 0.5$ and the upper dose limit to $I_{\gamma} \leq 1$, respectively [8].

The alpha index $\left(I_{\alpha}\right)$ corresponding to the excess alpha radiation due to the ${ }^{222} \mathrm{Rn}$ inhalation from cement was calculated using the following equation [15]:

$I_{\alpha}=\frac{A_{\mathrm{Ra}-226}}{200}$

The $I_{\alpha}$ should not exceed the unity since the radon exhalation from cement could cause an indoor radon concentration greater than $200 \mathrm{~Bq} \mathrm{~m}^{-3}[8,16]$.

\subsubsection{Excess lifetime of cancer risk}

The excess lifetime cancer risk (ELCR) was evaluated by the following formula $[17,18]$ :

$E L C R=A E D E \times R F \times D L$

where $\mathrm{RF}$ is the fatal cancer risk per Sievert $\left(0.05 \mathrm{~Sv}^{-1}\right)$ and DL the life duration (70 y).

\subsubsection{Effective dose rate to different organs and tissues}

The effective dose rate to different organs and tissues $\left(D_{\text {org }}\right)$ was calculated using the following equation $[19,20]$ :

$\operatorname{AEDE}\left(\mu \mathrm{Svy}^{-1}\right)=D\left(\mathrm{nGyh}^{-1}\right) \times 0.7\left(\mathrm{SvGy}^{-1}\right) \times 0.8 \times 8760 \mathrm{hy}^{-1} \times 10^{-3}$

The conversion coefficient of absorbed dose to an effective dose and the indoor occupancy factor used for the calculation of AEDE were $0.7 \mathrm{~Sv} \mathrm{~Gy}^{-1}$ and 0.8 , respectively [10].

$$
D_{\text {org }}\left(\mu \mathrm{Svy}^{-1}\right)=\mathrm{AEDE} \times \mathrm{CF}
$$


Table 1 Conversion coefficient $\mathrm{CF}$ for different organs or tissues [19]

\begin{tabular}{ll}
\hline Organ or tissue & $\begin{array}{l}\text { Averages } \\
\text { values of CF }\end{array}$ \\
\hline Bone marrow & 0.69 \\
Whole-body & 0.68 \\
Lungs & 0.64 \\
Ovaries & 0.58 \\
Testes & 0.82 \\
\hline
\end{tabular}

where $\mathrm{CF}$ is the conversion coefficient for the organ dose from air dose (Table 1).

\section{Results and discussions}

\section{1 ${ }^{226} \mathrm{Ra}$, ${ }^{232} \mathrm{Th}$, and ${ }^{40} \mathrm{~K}$ activity concentrations}

Table 2 reports the range and average of ${ }^{226} \mathrm{Ra},{ }^{232} \mathrm{Th}$, and ${ }^{40} \mathrm{~K}$ activity concentrations in the types of cement. The ${ }^{226} \mathrm{Ra}$ activity concentration in cement samples varied from $7.09 \mathrm{~Bq} \mathrm{~kg}^{-1}$ to $150.25 \mathrm{~Bq} \mathrm{~kg}^{-1}$. The ${ }^{232} \mathrm{Th}$ and ${ }^{40} \mathrm{~K}$ activity concentration in cement samples varied from 3.72 $\mathrm{Bq} \mathrm{kg}^{-1}$ to $16.09 \mathrm{~Bq} \mathrm{~kg}^{-1}$ and from $48.67 \mathrm{~Bq} \mathrm{~kg}^{-1}$ to $133.89 \mathrm{~Bq} \mathrm{~kg}^{-1}$, respectively.

As shown in Table 2, the highest average value of the ${ }^{226} \mathrm{Ra}$ and ${ }^{232} \mathrm{Th}$ activity concentrations was found in CEM I. The CEM IV (white cement) presented the lowest average value of activity concentration of these two radionuclides. Unlike the ${ }^{226} \mathrm{Ra}$ and ${ }^{232} \mathrm{Th}$, the highest average activity concentration of ${ }^{40} \mathrm{~K}$ was found in CEM IV and the lowest average value in CEM I. To make a comparison between the ${ }^{226} \mathrm{Ra},{ }^{232} \mathrm{Th}$, and ${ }^{40} \mathrm{~K}$ average activity concentrations and the worldwide average values in building materials, their respective ratios were calculated. The worldwide average values used for comparison were $50 \mathrm{~Bq} \mathrm{~kg}^{-1}, 50 \mathrm{~Bq} \mathrm{~kg}^{-1}$, and $500 \mathrm{~Bq} \mathrm{~kg}^{-1}$, respectively for ${ }^{226} \mathrm{Ra},{ }^{232} \mathrm{Th}$, and ${ }^{40} \mathrm{~K}[21$, 22]. In gray cements, the ratio ranges from 1.84 to 2.72 for ${ }^{226} \mathrm{Ra}$. Therefore, the ${ }^{226} \mathrm{Ra}$ activity concentration in gray cements was then found two times higher than the worldwide average value. In white cement, the ratio was 0.16 .
Then, the ${ }^{226}$ Ra average activity concentration in white cement was lower than the worldwide average value cited above. The ratio ranges from 0.24 to 0.30 for ${ }^{232} \mathrm{Th}$ and from 0.12 to 0.16 for ${ }^{40} \mathrm{~K}$ in the gray cement. In white cement, the ratios were 0.10 for ${ }^{232} \mathrm{Th}$ and 0.24 for ${ }^{40} \mathrm{~K}$. The ${ }^{232} \mathrm{Th}$ and ${ }^{40} \mathrm{~K}$ average activity concentrations were then below their worldwide average values in all types of cement.

The ${ }^{226} \mathrm{Ra},{ }^{232} \mathrm{Th}$, and ${ }^{40} \mathrm{~K}$ average activity concentrations in the gray and white cements were also compared with results from other countries (Table 3 ). The ${ }^{226} \mathrm{Ra}$ average activity concentration in gray cement was lower than that of Albania [23] and China [24]. It was higher compared to other countries. For ${ }^{232} \mathrm{Th}$, its average activity concentration was below the cited results in other countries. Regarding the average activity concentration of ${ }^{40} \mathrm{~K}$, this study was only lower than that of Albania [23]. The ${ }^{226} \mathrm{Ra}$ and ${ }^{232} \mathrm{Th}$ average activity concentrations found in white cement in this study had the lowest values. The result of the ${ }^{40} \mathrm{~K}$ activity concentration in Malaysia was only greater than this study [25].

\subsection{Dose parameters and radiological hazard indices}

The dose parameters and radiological hazards indices were evaluated and presented in Table 4.

The average values of the indoor absorbed gamma dose ranged from $22.09 \pm 2.10 \mathrm{nGy} \mathrm{h}^{-1}$ (CEM IV) to $146.41 \pm 6.98 \mathrm{nGy} \mathrm{h}^{-1}$ (CEM I). The indoor absorbed gamma dose rate in air of the types of cement exceeds the population-weighted average of $84 \mathrm{nGy} \mathrm{h}^{-1}$, except for CEM IV [10]. From Table 5, it can be seen that the average value of AEDE varied from $108.42 \pm 10.32 \mu \mathrm{Sv}^{-1}$ (CEM IV) to $718.72 \pm 34.26 \mu \mathrm{Sv}^{-1}$ (CEM I). The average value of AEDE of all types of cement is lower than the permissible limit which is $1000 \mu \mathrm{Svy}^{-1}$. Among the natural radionuclides, the principal contributor to the indoor AEDE was the ${ }^{226} \mathrm{Ra}$, with a contribution of $84 \%$ in gray cement. The ${ }^{226} \mathrm{Ra}$ was followed by ${ }^{232} \mathrm{Th}$ (11\%) and ${ }^{40} \mathrm{~K}(5 \%)$. In white cement, the principal contributor was ${ }^{40} \mathrm{~K}(43 \%)$, followed by ${ }^{226} \mathrm{Ra}(34 \%)$ and ${ }^{232} \mathrm{Th}(23 \%)$.

The average value of AGDE of the types of cement ranged from $81.84 \pm 7.88 \mu \mathrm{Sv}^{-1}$ (CEM IV) to
Table 2 Range and average with their standard deviation (SD) of ${ }^{226} \mathrm{Ra},{ }^{232} \mathrm{Th}$, and ${ }^{40} \mathrm{~K}$ activity concentrations in the types of cement

\begin{tabular}{llllll}
\hline $\begin{array}{l}\text { Activity concentrations in } \\
\mathrm{Bq} \mathrm{kg}^{-1}\end{array}$ & \multicolumn{4}{l}{ Type of cement* } \\
\cline { 3 - 6 } & \multicolumn{1}{l}{ CEM I } & CEM II & CEM III & CEM IV \\
\hline${ }^{226} \mathrm{Ra}$ & Range & $129.99-150.25$ & $75.36-149.96$ & $66.73-105.17$ & $7.09-9.24$ \\
& Average $\pm S D$ & $135.95 \pm 8.19$ & $109.95 \pm 28.42$ & $92.17 \pm 16.86$ & $8.07 \pm 0.81$ \\
${ }^{232} \mathrm{Th}$ & Range & $14.02-16.09$ & $10.15-13.27$ & $10.62-15.04$ & $3.72-5.85$ \\
& Average $\pm \mathrm{SD}$ & $15.09 \pm 0.83$ & $12.04 \pm 1.16$ & $12.24 \pm 1.74$ & $4.68 \pm 0.78$ \\
${ }^{40} \mathrm{~K}$ & Range & $48.67-66.22$ & $50.29 \pm 98.80$ & $52.00-95.72$ & $104.70-133.89$ \\
& Average $\pm \mathrm{SD}$ & $59.25 \pm 7.26$ & $80.72 \pm 18.26$ & $80.07 \pm 19.78$ & $118.91 \pm 11.88$ \\
\hline
\end{tabular}

*CEM I, CEM II, and CEM III: Portland cement composite; CEM IV: white cement 
Table 3 Comparison of ${ }^{226} \mathrm{Ra}$, ${ }^{232} \mathrm{Th}$, and ${ }^{40} \mathrm{~K}$ average activity concentrations of gray and white cements with those obtained in other countries

\begin{tabular}{llllll}
\hline Type & Country & \multicolumn{2}{l}{ Activity concentrations in $\mathrm{Bq} \mathrm{kg}^{-1}$} & References \\
\cline { 3 - 5 } & & \multicolumn{2}{c}{${ }^{226} \mathrm{Ra}$} & ${ }^{232} \mathrm{Th}$ & ${ }^{40} \mathrm{~K}$ \\
\hline Gray cement & Albania & $179.7 \pm 48.9$ & $55.0 \pm 5.8$ & $17.0 \pm 3.3$ & {$[23]$} \\
& Algeria & $41 \pm 7$ & $27 \pm 3$ & $422 \pm 3$ & {$[26]$} \\
& Cameroon & $27 \pm 4$ & $15 \pm 1$ & $277 \pm 117$ & {$[27]$} \\
& China & $118.7 \pm 14.2$ & $36.1 \pm 17.8$ & $444.5 \pm 163.1$ & {$[24]$} \\
& Egypt & $36 \pm 4$ & $43 \pm 2$ & $82 \pm 4$ & {$[28]$} \\
& Ghana & $35.94 \pm 0.78$ & $25.44 \pm 0.80$ & $233 \pm 3.95$ & {$[6]$} \\
& Iraq & $24.25 \pm 1.45$ & $25.41 \pm 1.65$ & $93.17 \pm 7.30$ & {$[4]$} \\
& Laos & $41.12 \pm 2.44$ & $16.60 \pm 2.37$ & $141.48 \pm 4.50$ & {$[29]$} \\
& Morocco & $31 \pm 5$ & $19 \pm 3$ & $238 \pm 29$ & {$[30]$} \\
& Pakistan & $25 \pm 10$ & $37 \pm 9$ & $245 \pm 95$ & {$[31]$} \\
& Turkey & $34 \pm 4$ & $15 \pm 2$ & $220 \pm 13$ & {$[9]$} \\
& Senegal & $112.69 \pm 26.02$ & $13.12 \pm 1.88$ & $73.35 \pm 18.12$ & In this study \\
& Cote d'Ivoire & $18.85 \pm 1.68$ & $22.94 \pm 1.96$ & $111.10 \pm 7.03$ & {$[32]$} \\
& Egypt & $15 \pm 3$ & $17 \pm 2$ & $10 \pm 5$ & {$[33]$} \\
& Qatar & $18.9 \pm 0.5$ & $4.9 \pm 0.5$ & $62.9 \pm 22.6$ & {$[34]$} \\
& Malaysia & $25.3 \pm 1.2$ & $23.4 \pm 1.2$ & $362.2 \pm 6.7$ & {$[25]$} \\
& Saudi Arabia & $28.53 \pm 3.75$ & $43.46 \pm 2.18$ & $67.38 \pm 3.36$ & {$[35]$} \\
& Senegal & $8.07 \pm 0.81$ & $4.68 \pm 0.78$ & $118.91 \pm 11.88$ & In this study \\
\hline
\end{tabular}

Table 4 Average with their standard deviation of dose parameters and radiological hazards indices according to the types of cement

\begin{tabular}{|c|c|c|c|c|c|}
\hline & & \multicolumn{4}{|l|}{ Cement type } \\
\hline & & CEM I & CEM II & CEM III & CEM IV \\
\hline \multirow[t]{3}{*}{ Dose parameters } & $D\left(\mathrm{nGy}^{-1}\right)$ & $146.41 \pm 6.98$ & $120.85 \pm 27.18$ & $104.67 \pm 16.42$ & $22.09 \pm 2.10$ \\
\hline & $\operatorname{AEDE}\left(\mu S v y^{-1}\right)$ & $718.72 \pm 34.26$ & $593.27 \pm 133.43$ & $513.80 \pm 80.63$ & $108.42 \pm 10.32$ \\
\hline & $\operatorname{AGDE}\left(\mu S v y^{-1}\right)$ & $501.75 \pm 23.15$ & $415.41 \pm 41.04$ & $361.11 \pm 24.93$ & $81.84 \pm 7.88$ \\
\hline \multirow[t]{3}{*}{ Radiological hazards indices } & $I_{\gamma}$ & $0.55 \pm 0.03$ & $0.45 \pm 0.10$ & $0.40 \pm 0.06$ & $0.09 \pm 0.01$ \\
\hline & $I_{a}$ & $0.68 \pm 0.04$ & $0.55 \pm 0.14$ & $0.46 \pm 0.08$ & $0.040 \pm 0.004$ \\
\hline & $\operatorname{ELCR}\left(10^{-3}\right)$ & $2.52 \pm 0.12$ & $2.08 \pm 0.47$ & $1.80 \pm 0.28$ & $0.38 \pm 0.04$ \\
\hline
\end{tabular}

Table 5 Effective dose rate to different organs and tissues according to types of cement

\begin{tabular}{llllll}
\hline $\begin{array}{l}\text { Type of } \\
\text { cement }\end{array}$ & \multicolumn{6}{l}{ Effective dose rate $\left(\mathrm{mSv}^{-1}\right)$} \\
\cline { 2 - 6 } & Lungs & Ovaries & $\begin{array}{l}\text { Bone mar- } \\
\text { row }\end{array}$ & Testes & Whole-body \\
\hline CEM I & 0.46 & 0.42 & 0.50 & 0.59 & 0.49 \\
CEM II & 0.38 & 0.34 & 0.41 & 0.49 & 0.40 \\
CEM III & 0.33 & 0.30 & 0.36 & 0.42 & 0.35 \\
CEM IV & 0.07 & 0.06 & 0.08 & 0.09 & 0.07 \\
\hline
\end{tabular}

$501.75 \pm 23.15 \mu \mathrm{Sv}^{-1}$ (CEM I). The average value of AGDE of CEM I, CEM II, and CEM III was higher than the worldwide average value of $300 \mu \mathrm{Sv} \mathrm{y}^{-1}$ calculated by considering a house containing worldwide average activity concentrations of ${ }^{226} \mathrm{Ra},{ }^{232} \mathrm{Th}$, and ${ }^{40} \mathrm{~K}$ in soil $[10,36]$.
Table 4 shows that the average value of the gamma Index $\left(I_{\gamma}\right)$ and the alpha index $\left(I_{a}\right)$ varied from $0.09 \pm 0.01$ (CEM IV) to $0.55 \pm 0.03$ (CEM I) and from $0.040 \pm 0.004$ (CEM IV) to $0.68 \pm 0.04$ (CEM I), respectively. The $I_{\gamma}$ in all types of cement was in the range of the exemption criterion $\left(I_{\gamma}<0.5\right)$ except the CEM I which was slightly greater but below the recommended limit $\left(I_{\gamma}=1\right)$ [8]. The $I_{a}$ of the types of cement was lower than the recommended limit value of 1 [8].

The ELCR for each type of cement is presented in Table 4 with an average value ranging from $(0.38 \pm 0.04) 10^{-3}$ (CEM IV) to $(2.52 \pm 0.12) 10^{-3}$ (CEM I). The excess lifetime cancer risk in all types of cement was higher than the worldwide average value which is $0.2910^{-3}$ [10]. The values of ELCR equivalent to $1000,100,10$, and $1 \mu \mathrm{Sv}^{-1}$ will increase the risk of developing mortal cancer by $4 \%, 0.4 \%, 0.04 \%$, and $0.004 \%$, respectively $[37,38]$. Even all ELCR calculated are 
higher than the worldwide value, the chances to increase the risks of cancer in life duration remains negligible.

The values of $D_{\text {org }}$ evaluated in different types of organs and tissues according to the types of cement shown in Table 5 were less than the set limit. The calculated values of $D_{\text {org }}$ showed that the testes were more sensitive to the radiations, and the ovaries were less sensitive.

\subsection{Statistical analysis}

\subsubsection{Descriptive statistics}

A descriptive statistics was performed to describe and also to have a better understanding of the statistical characteristic of the activity concentrations of the natural radionuclides $\left({ }^{226} \mathrm{Ra},{ }^{232} \mathrm{Th}\right.$, and $\left.{ }^{40} \mathrm{~K}\right)$. As the ${ }^{226} \mathrm{Ra}$ and ${ }^{232} \mathrm{Th}$ activity concentrations in white cement samples are found very low compared to gray cements, then they cause a large deviation of the distribution of the activity concentrations. Therefore, they are not used for the statistical analysis of the data. The results of the statisitical anlysis are reported in Table 6.

The skewness, kurtosis, and the $p$ value using the Shapiro-Wilks test were calculated to have a comprehensive understanding of the distribution of the data. The skewness characterizes the degree of asymmetry of the data [39]. In the theory of probability for a normal distribution, the skewness is equal to zero [40]. However, the data points are not always perfectly symmetric. The absolute magnitude of the ratio between the skewness and its standard error was calculated. If the ratio is less than two, the probability distribution can be assumed to be normally distributed. The distributions of ${ }^{232} \mathrm{Th}$ and

Table 6 Descriptive statistics of ${ }^{226} \mathrm{Ra},{ }^{232} \mathrm{Th}$, and ${ }^{40} \mathrm{~K}$ activity concentrations in cement samples

\begin{tabular}{|c|c|c|c|}
\hline & \multicolumn{3}{|c|}{ Activity concentration in $\mathrm{Bq} \mathrm{kg}^{-1}$} \\
\hline & ${ }^{226} \mathrm{Ra}$ & ${ }^{232} \mathrm{Th}$ & ${ }^{40} \mathrm{~K}$ \\
\hline Arithmetic mean $\pm \mathrm{MSD}^{*}$ & $112.69 \pm 6.72$ & $13.12 \pm 0.48$ & $73.35 \pm 4.68$ \\
\hline Standard deviation & 26.02 & 1.88 & 18.12 \\
\hline Geometric mean & 109.67 & 12.99 & 71.21 \\
\hline Min & 66.73 & 10.15 & 48.67 \\
\hline 25th percentile & 96.48 & 11.74 & 57.76 \\
\hline Median & 115.23 & 12.73 & 66.39 \\
\hline 75th percentile & 132.24 & 14.80 & 89.78 \\
\hline Max & 150.25 & 16.09 & 98.80 \\
\hline Skewness & -0.24 & 0.08 & 0.04 \\
\hline Kurtosis & -0.90 & -1.19 & -1.68 \\
\hline $\begin{array}{l}\text { Shapiro-Wilks test ( } p \\
\text { value) }\end{array}$ & 0.65 & 0.64 & 0.10 \\
\hline
\end{tabular}

*MSD Mean Standard Deviation
${ }^{40} \mathrm{~K}$ activity concentrations in this study had a weak positive skewness, whereas a weak negative skewness was observed for the distribution of ${ }^{226}$ Ra activity concentration. The ratios between the skewness and its standard error of the distributions of ${ }^{226} \mathrm{Ra}{ }^{232} \mathrm{Th}$ and ${ }^{40} \mathrm{~K}$ activity concentrations were found lower than two.

The kurtosis measures the extent of which data points cluster around the center of the distribution. For a normal distribution, the kurtosis is equal to zero. Negative kurtosis indicates that the data points are less clustered around the center, and the distribution has a thicker tail [41]. Unlike a negative kurtosis, the data points are clustered around the center of the distribution for a positive kurtosis and a thinner tail can be observed [41]. The ratio between the absolute magnitude and the standard error of the kurtosis must be less than two for a normal distribution. These ratios were found less than two for the distributions of ${ }^{226} \mathrm{Ra},{ }^{232} \mathrm{Th}$, and ${ }^{40} \mathrm{~K}$ activity concentrations.

The Shapiro-Wilks was also used to test the normality of the data. In the Shapiro-Wilks test, if the $p$ value is less than or equal to 0.05 , the distribution will not be normal. The found results in Table 3 show that the $p$ values were greater than 0.05 for the distributions of ${ }^{226} \mathrm{Ra}$, ${ }^{232} \mathrm{Th}$, and ${ }^{40} \mathrm{~K}$ activity concentrations.

The calculated values of the skewness, the kurtosis, and the $p$ value found by the Shapiro-Wilks test showed that the ${ }^{226} \mathrm{Ra},{ }^{232} \mathrm{Th}$, and ${ }^{40} \mathrm{~K}$ activity concentrations can be assumed normally distributed.

\subsubsection{Pearson correlation}

Pearson correlation analysis was performed to determine the interdependency and the strength of the relation between the natural radionuclides $\left({ }^{226} \mathrm{Ra},{ }^{232} \mathrm{Th}\right.$, and $\left.{ }^{40} \mathrm{~K}\right)$ in cement samples. The results of the Pearson correlation analysis are shown in Table 7. Between ${ }^{226} \mathrm{Ra}$ and ${ }^{40} \mathrm{~K}$, a weak negative correlation was observed, whereas a high positive correlation was observed between ${ }^{226} \mathrm{Ra}$ and ${ }^{232} \mathrm{Th}$. It indicates that ${ }^{226} \mathrm{Ra}$ and ${ }^{232} \mathrm{Th}$ have a common source which in general due to the mineralogical components [42]. A high negative correlation was found between ${ }^{232} \mathrm{Th}$ and ${ }^{40} \mathrm{~K}$ which can be due to the mineral composition in cement that can affect the mobility of radionuclides [42].

Table 7 Pearson correlation matrix for variables

\begin{tabular}{llll}
\hline Variables & ${ }^{226} \mathrm{Ra}$ & ${ }^{232} \mathrm{Th}$ & ${ }^{40} \mathrm{~K}$ \\
\hline${ }^{226} \mathrm{Ra}$ & 1 & & \\
${ }^{232} \mathrm{Th}$ & 0.60 & 1 & \\
${ }^{40} \mathrm{~K}$ & -0.23 & -0.76 & 1 \\
\hline
\end{tabular}




\section{Conclusion}

The ${ }^{226} \mathrm{Ra},{ }^{232} \mathrm{Th}$, and ${ }^{40} \mathrm{~K}$ activity concentrations were assessed in different types of cement available in Senegal by gamma-ray spectrometry. All activity concentrations were less than the worldwide values except the ${ }^{226} \mathrm{Ra}$ in the gray cement. The Raeq was found less than the recommended value. The absorbed dose rate was greater than the worldwide average value of $84 \mathrm{nGy} \mathrm{h}^{-1}$ only in the gray cement. The AEDE was less than the recommended limit of $1 \mathrm{mSv} \mathrm{y}^{-1}$. In the CEM I, CEM II, and CEM III, the AGDE was higher compared to the worldwide average of $300 \mu \mathrm{Sv}^{-1}$. The $I_{\gamma}$ of CEM I was only greater than the exemption criterion, but it was found below the recommended limit. The $I_{a}$ was slightly greater than the recommended exemption level value in the CEM I and CEM II. However, the alpha index of these two types of cement was below the recommended limit which indicates that the concentration of radon will be less than $200 \mathrm{~Bq} \mathrm{~m}^{-3}$. The calculated ELCR was greater than the worldwide value; however, the chances to increase the risks of cancer in lifetime remain negligible. The absorbed dose rate according to different types of organs or tissues showed that the testes are more radiosensitive and the higher values of different organs or tissues are found in the CEM I. The contribution of the radiological hazard from the cement under this study is not significant. However, the activity concentration of ${ }^{226} \mathrm{Ra}$ was found greater compared to its worldwide average value, which could serve as an alert to the radiation protection authority.

Acknowledgements The author would like to thank the International Atomic Energy Agency (IAEA) for the fellowship grant in the project SEN7005 "Supporting National Capabilities in Radioanalytical and Radiation Metrology Methods and Techniques". The author thanks also the Metrology of Environmental Radioactivity Laboratory (LMRE) of the Nuclear Safety and Radiation Protection Institute (IRSN) to have accepted to welcome the fellowship with the help of the European Nuclear Safety Training and Tutoring Institute (ENSTTI).

\section{Compliance with ethical standards}

Conflict of interest On behalf of all authors, the corresponding author states that there is no conflict of interest.

\section{References}

1. Bramha S, Sahoo SK, Subramanian V et al (2019) Application of multivariate technique to evaluate spatial distribution of natural radionuclides along Tamil Nadu coastline, east coast of India. SN Appl Sci 1:689

2. Eštoková A, Palaščáková L (2013) Assessment of natural radioactivity levels of cements and cement composites in the Slovak Republic. Int J Environ Res Public Health 10:165-7179
3. Senthilkumar G, Ravisankar R, Vanasundari K et al (2013) Assessment of radioactivity and the associated hazards in local cement types used in Tamilnadu, India. Radiat Phys Chem 88:45-48

4. Mansoor ZA, Nafae TM, Jelaot AKK (2018) Assessment of natural radioactivity levels and radiological hazards of cement in Iraq. Nucl Sci 3:23

5. Damla N, Cevik U, Kobya Al, Kobya A et al (2010) Radiation dose estimation and mass attenuation coefficients of cement samples used in Turkey. J Hazard Mater J 176:644-649

6. Kpeglo DO, Lawluvi H, Faanu A et al (2011) Natural radioactivity and its associated radiological hazards in ghanaian cement natural radioactivity and its associated radiological hazards in ghanaian cement. Res J Environ Earth Sci 3:161-167

7. IAEA (2011) Analytical methodology for the determination of radium isotopes in environmental samples. IAEA analytical quality in nuclear applications series no. 19

8. EC-European Commission (1999) Radiological protection principles concerning the natural radioactivity of building materials. Radiat Prot 112:1-16

9. Özdiş BE, Çam NF, Canbaz Öztürk B (2017) Assessment of natural radioactivity in cements used as building materials in Turkey. J Radioanal Nucl Chem 311:307-316

10. UNSCEAR (2000) United nations committee on the effect of atomic radiation soures, effects and risks of ionizing radiation. Report to the general assembly, Annex B. United Nations, NewYork

11. Mamont-Ciesla K, Gwiazdowski B, Biernacka M, Zak A (1982) Radioactivity of building materials in Poland. In: Vohra G, Pillai KC, Sadavisan S (eds) Natural radiation environment. Halsted Press, NewYork, p 551

12. UNSCEAR (1988) United nations committee on the effect of atomic radiation soures, effects and risks of ionizing radiation. Report to the general assembly, Annex A. United Nations, NewYork

13. Issa S, Mostafa AMA (2015) Distribution of natural radionuclide and radiation hazards of building materials used in Assiut, Egypt. Int J Bio-Sci Bio-Technol 7:115-130

14. El-Gamal H, Sidique E, El-Haddad M, Farid MEA (2018) Assessment of the natural radioactivity and radiological hazards in granites of Mueilha area (South Eastern Desert, Egypt). Environ Earth Sci 77:691

15. Righi S, Bruzzi L (2006) Natural radioactivity and radon exhalation in building materials used in Italian dwellings. J Environ Radioact 88:158-170

16. Viruthagiri G, Rajamannan B, Jawahar KS, Nagar A (2013) Radioactivity and associated radiation hazards in ceramic raw materials and end products. Radiat Prot Dosim 157:383-391

17. ICRP (1990) Recommandations of the international commission on radiological protection. Ann ICRP 21:1-3

18. Isinkaye MO, Emelue HU (2015) Natural radioactivity measurements and evaluation of radiological hazards in sediment of Oguta Lake, South East Nigeria. J Radiat Res Appl Sci 8:459-469

19. Darwish DAE, Abul-nasr KTM, El-khayatt AM (2014) The assessment of natural radioactivity and its associated radiological hazards and dose parameters in granite samples from South Sinai. J Radiat Res Appl Sci 8:17-25

20. Brien KO, Sanna R (1976) The distribution of absorbed dose-rates in humans from exposure to environmental gamma rays. Health Phys 30:71-78

21. NEA-OECD (1979) Exposure to radiation from the natural radioactivity in building materials Report by an NEA group of experts of the OECD. Nuclear Energy Agency, Paris

22. UNSCEAR (1993) Sources and effects of ionising radiation report to the general assembly, Annex B. United Nations, NewYork 
23. Xhixha G, Ahmeti A, Bezzon GP et al (2013) First characterisation of natural radioactivity in building materials manufactured in Albania. Radiat Prot Dosim 155:217-223

24. Lu X, Chao S, Yang F (2014) Determination of natural radioactivity and associated radiation hazard in building materials used in Weinan, China. Radiat Phys Chem 99:62-67

25. Yasir MS, Ab Majid A, Yahaya R (2007) Study of natural radionuclides and its radiation hazard index in Malaysian building materials. J Radioanal Nucl Chem 273:539-541

26. Amrani $D$, Tahtat $M(2001)$ Natural radioactivity in Algerian building materials. Appl Radiat Isot 54:687-689

27. Ngachin M, Garavaglia M, Giovani C et al (2007) Assessment of natural radioactivity and associated radiation hazards in some Cameroonian building materials. Radiat Meas 42:61-67

28. El-Taher A (2009) Gamma spectroscopic analysis and associated radiation hazards of building materials used in Egypt. Radiat Prot Dosim 138:166-173

29. Xayheungsy S, Khiem LH, Nam LD (2018) Assessment of the natural radioactivity and radiological hazards in Lao cement samples. Radiat Prot Dosim 181(3):208-213

30. Kassi B, Boukhair A, Azkour K et al (2018) Assessment of exposure due to technologically enhanced natural radioactivity in various samples of moroccan building materials. World J Nucl Sci Technol 8:176-189

31. Faheem M, Mujahid SA, Matiullah M (2008) Assessment of radiological hazards due to the natural radioactivity in soil and building material samples collected from six districts of the Punjab province-Pakistan. Radiat Meas 43:1443-1447

32. Alain MG, Huberson GBDL, Florentin BA et al (2019) Assessment of equivalent radium activity and annual effective dose due to building materials in cote d'ivoire by gamma spectrometry: cases of cement. Open J Appl Sci 9:774-783

33. Mahmoud KR (2007) Radionuclide content of local and imported cements used in Egypt. J Radiol Prot 27:69-77

34. Al-Sulaiti H, Alkhomashi N, Al-Dahan N et al (2011) Determination of the natural radioactivity in Qatarian building materials using high-resolution gamma-ray spectrometry. Nucl Instrum Methods Phys Res Sect A Accel Spectrom Detect Assoc Equip 652:915-919

35. Al-zahrani J, El-taher A (2017) Natural radioactivity levels and elemental analysis of cement by gamma-ray spectrometer and neutron activation analysis. Am Sci Res J Eng Technol Sci 30:173-183

36. Zaidi JH, Arif M, Ahmad S et al (1999) Determination of natural radioactivity in building materials used in the Rawalpindi/ Islamabad area by $\gamma$-ray spectrometry and instrumental neutron activation analysis. Appl Radiat Isot 51:559-564

37. Abdullahi S, Ismail AF, Samat S (2019) Determination of indoor doses and excess lifetime cancer risks caused by building materials containing natural radionuclides in Malaysia. Nucl Eng Technol 51:325-336

38. Gad A, Saleh A, Khalifa M (2019) Assessment of natural radionuclides and related occupational risk in agricultural soil, southeastern Nile Delta, Egypt. Arab J Geosci 12:188

39. Groeneveld RA, Meeden G (1984) Measuring Skewness and Kurtosis. Stat 33:391-399

40. Ravisankar R, Vanasundari K, Suganya M et al (2014) Multivariate statistical analysis of radiological data of building materials used in Tiruvannamalai, Tamilnadu, India. Appl Radiat Isot 85:114-127

41. Sahu SP, Yadav M, Das AJ et al (2017) Multivariate statistical approach for assessment of subsidence in Jharia coalfields, India. Arab J Geosci 10:191

42. Raghu Y, Ravisankar R, Chandrasekaran A et al (2017) Assessment of natural radioactivity and radiological hazards in building materials used in the Tiruvannamalai District, Tamilnadu, India, using a statistical approach. J Taibah Univ Sci 11:523-533

Publisher's Note Springer Nature remains neutral with regard to jurisdictional claims in published maps and institutional affiliations. 